PENTTI VARTIAINEN

\title{
Verbien nominaalirakenteista
}

Suomen kielelle, samoin kuin muillekin itämerensuomalaisille kielille, on ominaista runsas verbien nominaalimuotojen käyttö. Infinitiivejä, joita muissa Euroopan sivistyskielissä on tavallisesti vain yksi, on suomen kielessä perinnäisen käsitystavan mukaan viisi. Tärkeä kielemme erikoislaatua korostava piirre ilmaantuu nominaalimuotojen syntaktisessa käytössä: suomessa nominaalimuotoihin perustuu joukko omalaatuisia konstruktioita, nominaalirakenteita, joilla ei yleensä ole vastinetta indoeurooppalaisella taholla. Esim. parhaiten tuntemissamme germaanisissa kielissä ruotsissa, saksassa ja englannissa useat näistä konstruktioista joudutaan korvaamaan sivulauseella tai jollakin muulla analyyttisella ilmauksella.

E. N. SEтÄLän Suomen kielen lauseopin ensimmäinen, v. 1880 ilmestynyt painos, ensimmäinen suomenkielinen lauseoppi, tuntee verbien nominaalirakenteista vain partisiippirakenteen, "participiaalijärjestelmän" (ks. s. 45-47). Uusimmassa painoksessa on mainittu myös temporaali- ja finaalirakenteet (14., Matri SAdenIEMEN tark. p. s. 40). Samalla tai likipitäen samalla kannalla ovat kaikki nykyiset koulukieliopit. Verbien nominaalirakenteita on kuitenkin huomattavasti enemmän, kuin SETÄLän lauseoppi esittää. LAURI HAKULISEN Suomen kielen rakenne ja kehitys -teoksen 2. osassa esitellään partisiippi-, temporaali- ja finaalirakenteiden lisäksi kvasi- ja modaalirakenne, kvantum- ja fatumrakenteet sekä agenttirakenteet (s. 543568). Aarni Pentrilän Suomen kielioppi, jossa puheena olevista rakenteista on täydellisin kokonaisesitys, jatkaa luetteloa vielä muutamilla rakenteilla. Ne ovat intensiteettirakenteet, infinitiivirakenteet sekä nimettömät rakenteet $m i n u n$ on meneminen, minun

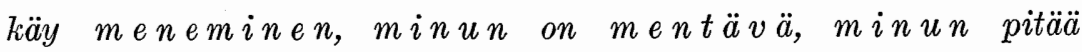
kirjoittaman ja minun tuli mennyksi (ks. s. 632-643 
sekä asiahakemisto). ${ }^{1}$ Kun näihin vielä lisätään attribuuttirakenne, josta EEva LindéN on kirjoittanut Virittäjässä v. 1962 (s. 216-), on koko käsiteltäväksi aiotusta rakennekompleksista kirjallisuuden perusteella muodostuva kokonaiskuva valmis. Esimerkkejä eri rakenteista:

Partis i p p i r a k e n ne: Kuulin käen kukkuvan (SKRK II 544) | Sano sanoneeni (ib.) | Näin kaksi konetta putoavan (ib.) Näkyy tulevan sade (ib. 545) | Kuului käyneen vieraita (ib.).

Te m p raalirakenn e: Ei kukaan ole seppä syntyessään sl. (SKRK II 553) | Kova on surma silmin nähden, kuolema käsin pidellen sl. (ib.) | Hyvä koira kuoltuansa, ilkeä eläessänsä sl. (ib. 554).

F in a a lirakenne: Saadakseen susi ulvoo (SKRK II 560) | Juokse joutuaksesi ajoissa (ib.) | Tuon vettä juodaksesi (Penttilä SK § 327 I, vrt. SKRK II § 37 f 3 ).

K vasirakenn e: Kylläpä on olevinaan (SKRK II 551) |

Vie sinä, minä vikisen, ole viepinäs väkisin hoku (ib.).

M o d a a li raken n e : Ei kukko käskien laula sl. (SKRK II 557) | Sanoin asiani kaikkien kuullen (ib.) | Lapsi vaipui uneen

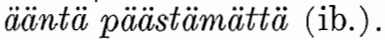

$\mathrm{K}$ v a n t u m rakenn e: Tässä ei nähdälsseni auta muu kuin kovuus (SKRK II 560) | Kaikki kutsutut eivät huomatakseni olleet läsnä (ib.).

F a tumrakenne: Ei tule, jos ei ole tullakseen (SKRK II 561) | Kyllä se tauti siitä menee, jos on mennäkseen (ib.).

A g e $n$ t t i r a k n n e : Lämmitimme majaa veden tuomilla ajopuilla (SKRK II 562) | Tällaiset eivät ole lasten kuultavia puheita (ib. 563) | Ei pyyssä kahden jakaa sl. (ib. 564) | Toin sen tänne katsoaksesi (ib.), vrt. PENTTILÄ SK $\S 327$ I). ${ }^{2}$

Intensite ettirakenne: Nauroin ihan katketakseni (Pentтilä SK § 327 I 2) | Sydän sykkii pakahtuakseen (ib.).

In finiti i virake n n e: Anna pojan mennä (PentTilä SK 640) | Sallikaa lasten tulla minun tyköni UT (ib. 641) | Varastoon annettiin jäädä kelkka ja sukset (ib.) | Vian täytyy olla generaattorissa - Generaattorissa täytyy olla vika (ib.) | Minun on vaikeata tulla (ib. 642).

1 Pentrilä nimeää myös samalla kuin- eli simulrakenteet (SK s. 638). Näissä ei kuitenkaan ole kysymys uudentyyppisistä rakenteista vaan uudesta nimityksestä eräille temporaali- ja modaalirakenteille.

2 Agenttirakenteen predikaattiosassa voi esiintyä myös 3. infinitiivistä -ton, -tön -johtimella muodostettu karitiiviadjektiivi (ks. HAKULINEN SKRK II s. 562, $564)$. 
A t tribu ut tirakenn e: Pojat pelkäsivät ankaruudestaan tunnettua opettajaa (LINDÉN Vir. 1962 s. $216^{3}$, alk. SETÄL̈̈ SKL $88) .^{4}$

Nimityksellä verbin nominaalirakenne voidaan tarkoittaa muunkinlaisia konstruktioita, joissa verbin nominaalimuoto on keskeisessä asemassa (rakenteestahan voidaan puhua aina silloin, kun on vähintään kaksi konstruktioelementtiä olemassa), mutta on tarkoituksenmukaista käyttää tätä nimitystä vain esitetyistä konstruktioista, jotka selvästi erottuvat muista ilmauksista omaksi ryhmäkseen (ks. s. 87).

Nykyiseen käsitykseen tai oikeammin nykyisiin käsityksiin verbien nominaalirakenteista on tultu vähitellen. Tässä yhteydessä ei ole mahdollista edes pääpiirteittäin referoida kehityksen kulkua; on vain tyydyttävä nimeltä mainitsemaan huomattavimmat tutkijat Lauri Hakulinen, Osmo Irola, Aarni Pentrilä ja Paavo Siro. Niin paljon kuin eri tutkijain käsitykset saattavatkin poiketa toisistaan, nominaalimuotojemme syntaktisen luonteen tulkinnan muuttumisessa on havaittavissa yhteinen linja: SEтÄLän analyyttinen tulkinta, joka viime kädessä perustui vieraiden kielten kielioppien tarjoamiin kaavoihin, on vähitellen muuttunut yhä synteettisemmäksi, ilmeisesti kielemme omaa luonnetta paremmin vastaavaksi. - Verbien nominaalirakenteihin liittyvä probleemisto on hyvin moninainen. Tässä voin ottaa esille vain muutamia kysymyksiä.

Rakenteiden nimistö. Rakenteet on nimetty vähä vähältä aina sitä mukaa, kuin uusia on löydetty. Tässä on tärkein syy siihen, että rakenteiden nimistöstä on tullut heterogeeninen ja osaksi sekava. Jos, yksityisen esimerkin ottaaksemme, muunnamme passiivisen attribuuttirakenteen Pojat pelkäsivät ankaru udesta an tu n n e t tu a opettajaa aktiiviseksi sijoittamalla siihen subjektin: P. p. kaikkien ankaruudesta tuntemaa o., se muuttuukin agenttirakenteeksi! On siis kysymys pohjimmaltaan samasta rakenteesta, jonka kutsumista kahdella nimellä ei voitane pitää eri-

${ }^{3}$ LINDÉN lukee attribuuttirakenteihin muunkinlaisia kuin ankaruudestaan tunnettu opettaja -tyyppisiä ilmauksia (Vir. 1962 s. 216-217), mutta ne eivät kuulu tähän esitykseen.

4. Ylempänä mainitut PhNтTILÄn nimettömät rakenteet on jätetty esimerkistöstä pois. 
tyisen onnistuneena ratkaisuna. Agenttirakenne ei sovellu puheena olevan passiivisen rakenteen nimeksi, koska tästä, samoin kuin muistakin suomen passiivi-ilmauksista, puuttuu kieliopillinen tekijä. Attribuuttirakenne olisi yhteisnimitykseksi mahdollinen. Tällöin vanha agenttirakennekategoria hajoaisi, sillä osa agenttirakenteiksi kutsutuista konstruktioista, esim. Ei pyyssä $k a h \not d e n j a k a a$, on lauseenjäsenenä abverbiaali eikä attribuutti. Eri asia on, onko attribuuttirakenne koko nominaalirakenteiston kannalta tarkoituksenmukainen nimitys.

Rakenneterminologiassa on havaittavissa muutakin epäjohdonmukaisuutta. Eniten sekaannusta aiheuttaa se, että nimitysperusteet menevät päällekkäin, kun osa nimityksistä (esim. infinitiivirakenne ja partisiippirakenne) viittaa rakenteen $\mathrm{mu}$ ot o o $\mathrm{n}$, osa s is ältöö $\mathrm{n}$ (esim. temporaalirakenne ja finaalirakenne). Konkreettiseksi esimerkiksi siitä, mihin kahtalaisen selitysperustan käyttäminen on johtanut, sopii rakennetyyppi Toin sen tänne $k$ atsoals esi, jota HAKULINEN muodollisin perustein nimittää agenttirakenteeksi (SKRK II § 37 f 3), mutta PenTtiLä sisällöllisin perustein finaalirakenteeksi (sehän vastaa finaalista jotta-lausetta) (SK $\S 327$ I). Nimenanto olisi pitänyt voida suorittaa kokonaan yhtäläisen periaatteen mukaan. Luonnollisinta olisi varmaan ollut jakaa rakenteet ensiksi infinitiivi- ja partisiippirakenteihin ja ne taas edelleen samanlaisin 1. muodollisin perustein. Siitä olisi tietysti seurannut, että esim. temporaalirakenteet olisivat osaksi infinitiivirakenteita (Ei kukaan ole sepp $\ddot{a}$ s y nty ess $\ddot{a} \ddot{a} n$ ), osaksi partisiippirakenteita (Hyvä koira kuoltuansa). Tämä olisi kuitenkin pienempi paha kuin se, että esim. agenttirakenteihin sellaisena ryhmänä, jona HAKULINEN on ne esittänyt (SKRK II s. 562-), kuuluu nyt ns. agenttipartisiippiin, passiivin 1. partisiippiin, aktiivin 1. infinitiiviin ja 3 . infinitiivistä muodostuneeseen karitiiviadjektiiviin perustuvia rakenteita. Näillähän ei ole muuta yhteistä kuin "toimittava persoona, agentti", rakenteen sisäisten suhteiden kannalta oikeammin subjekti, joka yleensä on kaikilla muillakin aktiivisilla rakenteilla. Sitä paitsi mikään ei olisi estänyt tekemästä toista ryhmittelyä sisällöllisin perustein, mikäli sellainen olisi katsottu välttämättömäksi.

Nimikysymys on vaikea kysymys. On paljon helpompaa osoitella vikoja rakenteiden nykyisestä nimistöstä kuin laatia konkreettinen 
ehdotus uusiksi nimiksi. Jos nykyinen nimistö katsotaan niin vakiintuneeksi, että sen muuttaminen ei enää lzäy päinsä, voitaisiin minusta varsinaisiin nimenmuutoksiin ryhtymättäkin käyttää nimityksiä infinitiivi- ja partisiippirakenne myös niiden luonnollisessa merkityksessä, yleisnimityksinä, siis tarkoittamassa jokaista infinitiiviin ja partisiippiin perustuvaa nominaalirakennetta. Osaksi näin on jo tehtykin, sillä O. IKoLA on tarkoittanut edellisen nimityksen myös kaikkien infinitiiviin perustuvien rakenteiden yhteisnimeksi (Vir. 1954 s. 218 alaviite). PeNTTILÄkin mainitsee lyhyesti infinitiivirakenteina myös temporaali-, modaali-, fatum-, intensiteetti- ja finaalirakenteen (SK s. 641). Ryhmänimitysten tarve on siis ilmeisesti olemassa.

Rakenteen subjekti- ja predikaattiosa. Verbien nominaalirakenteille on usein tunnusomaista jalkaantuminen ns. subjekti- ja predikaattiosaan. Yleisen terminologisen käytännön mukaan esim. partisiippirakenteen Äsken kuulutettiin ensimm ä $i s$ ten kilpailijoiden sa a p n e en ma aliin paikalla mahdollisen että-lauseen subjektin vastinetta kilpailijoiden olisi nimitettävä rakenteen subjektiosaksi ja predikaatin vastinetta saapuneen sen predikaattiosaksi. Ettei tätä terminologiaa ole aina pidetty tarpeeksi eksaktina, osoittaa se, että edellisestä rakenteen jäsenestä on myös käytetty mm. nimitystä s u b j e kt i (ks. O. TKoLA Vir. 1954 s. 217 218). Jos jälkimmäistä jäsentä nimitettäisiin rakenteen p r e dika atiksi, käsitteet subjekti- ja predikaattiosa vapautuisivat tarkoittamaan rakenteen subjektia ja predikaattia määritteineen. Ainahan määritteitä ei tietenkään ole. Esimerkkirakenteessamme siis ensimmäisten kilpailijoiden olisi subjektiosa ja saapuneen maaliin predikaattiosa. Sana kilpailijoiden olisi rakenteen subjekti ja saapuneen sen predikaatti. Tätä käsiteaparaattia on jo käytetty lauseen analysoimiseen SETÄLÄn-NIEMISEN Suomen kielen oppikirjassa, jossa subjektin määritteineen sanotaan muodostavan lauseen subjektiosan ja predikaatin määritteineen sen predikaattiosan (s. 68-69).

$\mathrm{Pas}$ aiviset rakenteet ovat vastaavien sivulauseiden tavoin subjektittomia. Esim. Luulen $h$ a $k$ e $m u k s e n h y v \ddot{a} k s$ y $t$ t $\ddot{a} v \ddot{a} n$ (partisiippirakenne) (SKRK II 545) | Ha luttaessa työt noudetaan tilaajan kotoa (temporaalirakenne) (ib. 553). On muitakin yksipersoona is i a rakenteita, joista subjekti puuttuu. Esim. Siin' on työ tyhjällä $r i k k a a k s i$ py $r k i$ ess $\ddot{a}$ (temporaalira- 
kenne) (ib. 554) | Ei uni ma aten lopu (modaalirakenne) (ib. 557). Näyttäisi siltä, ettei sana rakenne ole oikein sopiva nimitys sellaisille määritteettömille ilmauksille kuin haluttaessa ja maaten, jotka lauseopin kannalta ovat jakaantumattomia. Jos pysyttelemme puhtaasti ki eli o p ill i s ell a tasolla, emme voi nimittää näitä ilmauksia rakenteiksi, koska ne eivät rakennu mistään. L o o g i s e 11 a tasolla asia on toisin, sillä sekä passiiviset että muutkin mainitut ilmaukset edellyttävät lisäjäsentä, tekijää, a ja t u s s u b jektia. Niitä sopisikin ehkä nimittää piileviks i raken teiksi, joihin olisi mahdollista lukea myös esim. sellaiset tyypit kuin Pitää m e n n $\ddot{a}$ ja Anna ol la, jotka eroavat kieliopillisista infinitiivirakenteista

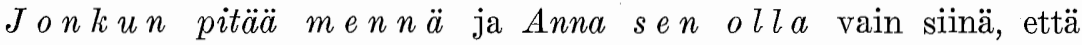
cdellytetty subjekti on jätetty mainitsematta.

Tarkasteltavana olleiden rakenteiden predikaattina on ollut verbin nominaalimuoto. Alumpana esiteltyjen nimettömien rakenteiden predikaattiosaan kuuluu PeNtrilän mukaan myös verbin finiittimuoto. Hän nimittäin selittää nuo ilmaukset, joille on yhteistä genetiivimuodossa oleva tekijä, seuraavalla tavalla: esim. lauseessa Minun on meneminen tiivis sanaliitto on meneminen, joka on verrattavissa tempussanaliittoihin on mennyt jne., muodostaa genetiivin täydentämänä neksuksen (SK s. 642). Toisin sanoen lauseen kaikki sanat kuuluvat rakenteeseen siten, että genetiivissä oleva sana on rakenteen subjekti ja kaksi muuta sanaa yhdessä sen predikaatti. Jos tämä lausetyyppi käsitetään Penтtılän tavoin yhdeksi neksukseksi, siinä ei ole kysymys partisiippi-, temporaali- yms. rakenteihin verrattavasta rakenteesta; emmehän sano tämmöiseksi rakenteeksi esim. lausetta Hän on mennyt, johon lause Minun on meneminen PeNTTILän tavalla käsitettynä rinnastuu. Muuta tarkoittaen voimme tietenkin mistä tahansa lauseesta käyttää nimitystä rakenne. Jos lausetyyppi käsitetään toisin, niin että genetiivimuotoinen sana ymmärretään nominaalimuodon subjektiksi, on kysymyksessä nominaalirakenne, johon lauseen predikaattina oleva verbin finiittimuoto ei kuulu sen paremmin kuin tämäntapaiseen rakenteeseen muulloinkaan ${ }^{5}$. Tämän käsitysta-

\footnotetext{
` Fatumrakenne käsitettynä perinnäisellä tavalla, esim. "Kyllä se tauti siitä menee, jos on mennäkseen" (SKRK II 561), on poikkeus. Rakenteesta voidaan kuitenkin myös tässä tapauksessa puhua sisällyttämättä siihen verbin finiittimuotoa, jos infinitiivin possessiivisuffiksi käsitetään rakenteen toiseksi jäseneksi.
} 
van mukaan siis puheena olevassa lauseessa Minun on meneminen on kaksi neksusta: rakenne minun meneminen sekä sen ja verbin finiittimuodon muodostama.

Joukko nominaalimuotojen esiintymistä on sellaisia, että ne eivät muodosta tässä kirjoituksessa tarkoitetun lajista nominaalirakennetta. Vastikään oli puhetta tapauksesta, jossa partisiippi on tempussanaliiton osana muodostamassa verbin finiittistä liittomuotoa (on mennyt). Pari esimerkkiä muunlaisista partiippitapauksista: $M a$ javanhampaan t a p p a va n voiman saattoi tartuttaa kirveeseenkin Samuli Paulaharju (Siro SKL 141) | Ka $u$ h is $t u$ n e e n a kuunteli kansa pappinsa pauhaamista PaulaharJu (ib. 144). Tällaiset partisiippiesiintymät eivät ratkaisevasti poikkea rakenteisiin kuuluvista, koska näilläkin on itse asiassa s u b j ekti: voiman, kansa, joka tosin varsinaiselta tehtävältään on muu lauseenjäsen: objekti, subjekti. Infinitiivien suhteen päädymme samaan tulokseen. Muuta-

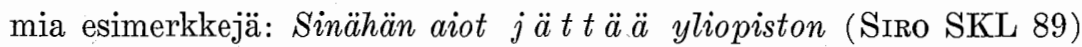
| Hän kumartui ot tama an oksaa maasta (ib. 107) | Leikin meno pakottaa yksilön a lis t a m a a n tahtonsa määrättyihin sään-

- töihin (ib.). Infinitiivin subjektin ilmaisevat sanat ovat sinähän, hän ja yksilön, joista kaksi ensimmäistä on lauseessa subjektina ja viimeinen objektina (SıRo mts. 89, 107). Lausetyypeissä Vastasin

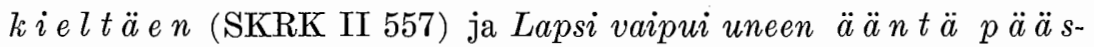
$t \ddot{a} m \ddot{a} t t \ddot{a}$ (ib.), joissa lauseen subjekti ja infinitiivin subjekti myös ovat yksi ja sama: edellisessä esimerkissä verbin persoonamuotoon sisältyvä ja jälkimmäisessä sana lapsi, HAKuLINEN on selittänyt olevan nominaalirakenteen, nimittäin modaalirakenteen (SKRK II s. 557). 2. infinitiivin instruktiivia vastaavaa infinitiiviadessiivia, esim. Teerï̈ saa talvella myös a j a malla AHti RytкöNeN (SIRo SKL. 113), ei ole luettu samoihin rakenteihin. Yhtenä syynä, kuten SIRo lauseopissaan mainitsee (s. 113), on ollut se, että tällä muodolla ei ole tavattu erillistä tekijää. ${ }^{6} 2$. infinitiivin instruktiivilla ja 3 . infinitiivin abessiivilla sen sijaan voi olla oma tekijä (Sanoin asiani $k a i k$ -

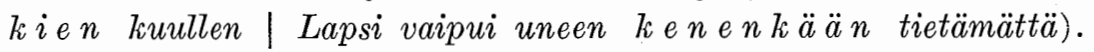
Tässä meillä on kriteeri, jonka perusteella voimme erottaa nominaali-

- Rajan vetäminen tällä tavalla ei ole kaikin puolin tyydyttävä ratkaisu, koska 2. infinitiivin instruktiivinkin esiintymissä on sellaisia, jotka eivät missään tapauksessa voi saada erillistä tekijää, esim. yllä oleva kieltäen. 
rakenteet muista ilmauksista. Verbin nominaalirakenne on vain sellainen ilmaustyyppi, jossa nominaalimuodolla - passiivitapauksia tietenkin lukuun ottamatta — on joko faktillisena tai mahdollisena muodollisesti e rilli n e $\mathbf{n}$ s ubjekt $i$, joksi riittää possessiivisuffiksikin.

Nominaalirakenteen subjektin ja predikaatin välisestä suhteesta sekä näiden muodostamasta kokonaisuudesta on ruvettu käyttämään nimitystä neksus, joka on kuitenkin laajempi käsite mm. siten, että se kuvaa myös lauseen subjektin ja predikaatin keskinäistä suhdetta sekä näiden muodostamaa sanaliittoa. Käsite neksus, joka on peräisin Adolf Noreenin tutkimuksista, on saanut huomattavan tieteellisen merkityksen vasta Отто JEsPERsENin kehittämänä ja täsmentämänä (ks. esim. The Philosophy of Grammar s. 114-). Suomenkielisessä kirjallisuudessa neksus on haluttu rajoittaa tarkoittamaan vain sellaisia sanaliittoja ja kieliopillisia suhteita, jotka eivät ole alisteisia eivätkä rinnasteisia (ks. PENTriuä Vir. 1956 s. 122-123 ja Srro SKL s. 16). Tämän käsitystavan mukaan passiiviset ja muutkin kieliopillista subjektia vailla olevat rakenteet, joista taannoin oli puhetta, jäävät neksus-kategorian ulkopuolelle. JEsPERSENin filosofista tulkintaa noudattaen nämäkin, koska ne edellyttävät ajatussubjektia, ovat käsitettävissä neksuksiksi. Niitä voitaisiin erotukseksi kieliopillisista neksuksista nimittää p i i l e viks i n e ks uks i ksi.

Rakenne ja la us e envastike. Tehtäessä selkoa verbien nominaalirakenteista on säännöllisesti, sikäli kuin olen pannut merkille, turvauduttu käsitteeseen lauseenvastike. Termi ei ole yksiselitteinen.

Aluksi on syytä huomauttaa, että verbien nominaalirakenteet eivät ole ainoat ilmaukset, joita on nimitetty lauseenvastikkeiksi, niin kuin koulukielioppien perusteella helposti saattaisi luulla. HAKULINEN on lukenut lauseenvastikkeihin nominativus ja partitivus absolutukset, esim. Hattu p $\ddot{a} \ddot{a} s s \ddot{a}$ herrat käyvät, kuningas ky $p \ddot{a} r \ddot{a} \quad p \ddot{a} \ddot{a} s$ $s \ddot{a}$ sl. | Tulipa repo ke it etyit $\ddot{a}$ he r ne it $\ddot{a}$ su uss a kansansadusta, jotka vastaavat sivulausetta (ks. SKRK II s. 541-542). Tarkemmin sanoen ne vastaavat modaalista nïn ( siten) että-lausetta (toisin Siro SKL s. 55). Että-lauseella on mahdollista korvata osa ns. substantiivirakenteista, esim. Olemme maininneet $S$ nellmanin yrityksen saada kysymys rahareformis- 
ta lo pullisesti ratkaistuksi (PentTILÄ SK 597), joita LrNDÉN pitää lauseenvastikkeina (ks. Vir. 1962 s. 217). ${ }^{7}$ Lisäksi on olemassa ainakin pari ilmaustyyppiä, joita kirjallisuudessa on nimitatty lauseenvastikkeiksi sillä perusteella, että ne voidaan korvata sivulauseella. Toinen näistä on predikatiivinen lauseenvastike, rinnakkaiselta ja enemmän käytetyltä nimeltä appositio (ks. SETÄL̈̈ SKL s. 35- ja esim. Penttilä SK s. 351-). Nimitys predikatïvinen lauseenvastike ${ }^{8}$ on tietääkseni MarTti Airilan lauseopissaan käyttöön ottama (ks. SKL s. 35), ja se esiintyy lisäksi esim. KetTuseN-Vaulan Suomen kieliopissa (s. 168-169) ja SaArimaan Kielenoppaassa (s. 202). Esim. Van he mp a na (= Koska olen vanhempi) minun on neuvottava sinua (KETTUNEN-VAULA SK 168)|H $\ddot{a} n$ e $n$ l u oks e ns a tull le in a [=Kun olemme tulleet hänen luoksensa]

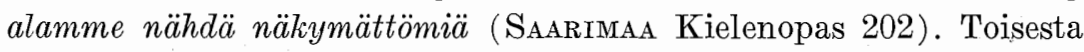
tyypistä PentriLällä on esimerkkinä tietää jokin jonkun a in o a ks $i$ huvilksi (= että jk on jkn ainoa huvi) (SK § 2592 ). Tapauksia, joissa jokin muu kuin tässä esityksessä verbien nominaalirakenteihin luettu ilmaustyyppi vastaa sivulausetta, on muitakin. Pari esimerkkiä: Attribuuttina oleva aktiivinen partisiippi ${ }^{9}$ on mahdollista korvata samassa asemassa olevalla relatiivilauseella, esim. Ojan reunalla istui $i t k$ e $v \ddot{a}$ poika $=0 . r . i . p ., j$ ok a $i t k i$ (SETÄLÄ -Nieminen SKO 179). Lausetyypissä Tulin s o u t a mall a oleva infinitiiviadessiivi, joka vastaa 2 . infinitiivin instruktiiviin perustuvaa modaalirakennetta, voidaan HAKULISEN mukaan korvata tapaa ilmaisevalla (siten) että -lauseella (SKRK II s. 556, 558). Mikään ei käsittääkseni estä nimittämästä myös näitä viimeksi puheena olleita ilmauksia lauseenvastikkeiksi, koska ne kerran vastaavat sivulausetta.

Mitä tulee nimenomaan verbien nominaalirakenteihin, joiden yhteydessä lauseenvastike-käsitteellä on ollut eniten käyttöä, lauseenvastike on havaintojeni mukaan selitetty kahdella tavalla. Tavallises-

${ }^{7}$ Siron lauseopissa termillä substantiivirakenne on huomattavasti laajempi merkitys (ks. s. 124-).

$s$ Prof. O. IkoLA mainitsi kerran suuliisesti pitävänsä tätä nimitystä parempana, koska appositio-termillä on kielitieteessä ennestään toisenlainen tehtävä (ks. esim. ERKKI Ituronen Kieli ja sen tutkimus s. 257).

- Vastaavat passiivin partisiipit muodostavat agentti- ja attribuuttirakenteita (lasten kuultcvat puheet | ankaruudestaan tunnettu opettaja). 
ti, niin kuin esim. PeNTTILÄn kieliopissa, sillä tarkoitetaan r a k e nnetta, joka voidaan korvata sivulauseella (ks. SK $\S$ 453). Niinpä PentriL Ä selittää nominaalirakenteet lauseenvastikkeiksi lukuun ottamatta fatumrakenteita, ns. nesessiivisiä ja objektina olevia infinitiivirakenteita sekä nimettömiä rakenteita (mts. 492-497, 632-643). Hän tosin huomauttaa, että partisiippirakenteissa on sellaisia, joiden paikalle on hankala sijoittaa että-lausetta. Esim. As $i$ as t a kuuluu $t$ e h dy $n$ p äa $t \ddot{o} s$ on vaivoin muunnettavissa:

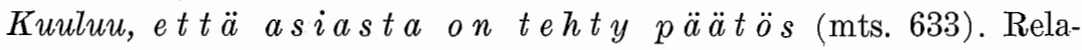
tiivilauseeseen kuuluva partisiippirakenne on, niin kuin hän toteaa, mahdoton korvata että-lauseella: Tekijä on käsitellyt aihetta, jo $n k a$ -

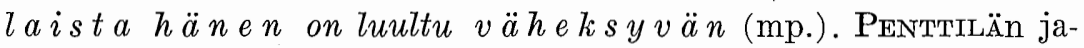
koon on muunkinlaista huomautettavaa. Infinitiivirakennetyyppeihin, joita hän ei pidä lauseenvastikkeina, sisältyy hänen oman esimerkistönsäkin perusteella rakenteita, jotka selvästi vastaavat että-lausetta. Esim. Sallikaa lasten tulla minun tyk öni UT (SK 641)

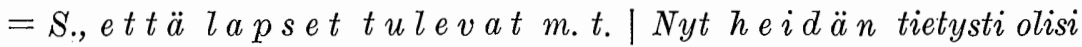
sopinut erinomaisesti m e n $n \ddot{a}$ na $i m i$ siin EINo LEINo (ib. 467) $=N$.t.o.s. e., ett $\ddot{a}$ he olisivat menneet naimisiin.

Muuan tällä tavalla ymmärrettyyn lauseenvastike-käsitteeseen liittyvä aika tärkeä seikka, johon suomen kielen osalta ei ole kiinnitetty huomiota, on se, että agentti- ja attribuuttirakenteilla on hallitsevan lauseen kanssa yhteinen jäsen. ${ }^{10}$ Havainnollistaakseni asiaa siteeraan HAKULISELTA pari agenttirakenne-esimerkkiä: "Lämmitimme majaa veden tuomilla ajopuilla" (SKRK II 562) | "Toin sen tänne katsoaksesi” (ib. 564). Edellisen esimerkin sana ajopuilla on lauseenjäsenenä adverbiaali, mutta samalla agenttipartisiipiksi kutsutun nominaalimuodon looginen objekti, jälkimmäisen esimerkin sana sen taas varsinaiselta tehtävältään objekti, mutta myös infinitiivin looginen objekti. Jos korvaamme rakenteet sivulauseella: L.m.a., jotka vesi olituonut | T.s.t., jottakatsoisit sitä, puheena olevien sanojen kahtalainen tehtävä käy yhä ilmeisemmäksi, koska niillä on sivulauseessa pronominivastine (jotka, sitä). Selvintä varmaan olisi, jos tällaisissa tapauksissa jollain erityisellä merkin-

10 Niin kuin Eeva KangasmaA-MINN on osoittanut, tšeremissin agenttirakenne on tässä suhteessa samanlainen (ks. The Syntactical Distribution of the Cheremis Genitive s. 188). 
nällä voitaisiin osoittaa määräsana sekä lauseen että rakenteen jäseneksi. HAKULINEN käyttää, nüin kuin näkyy, kahta merkintätapaa: edellisessä esimerkissä hän lukee tarkasteltavana olevan sanan rakenteeseen, jälkimmäisessä jättää lukematta. Jälkimmäinen tapa on ilmeisesti parempi, koska kaksifunktioinen sana on kuitenkin ensijaisesti varsinainen lauseenjäsen.

Yllä lauseenvastikkeen tuntomerkkinä käytetty rakenteen ominaisuus: vain sellainen rakenne on lauseenvastike, joka esiintymisyhteydessään voidaan korvata sivulauseella, on suhteellisen yksiselitteinen, koska se olennaisesti riippuu rakenteen sisältävän lauseen predikaattiverbistä. Verrattakoon vain toisiinsa esim. rakenteita $A n n a$ v e d e n valua ja Sallin veden valua, joista vain jälkimmäinen on suoralta kädeltä korvattavissa että-lauseella. Selvittämistä sen sijaan kaipaisi, mitkä ovat eri rakenteiden ja niiden paikalla mahdollisten sivulauseiden esiintymäfrekvenssit ja mahdolliset funktioerot.

Suomen kielestä puhuttaessa edellä selostetun laisesta lauseenvastike-käsitteestä on suurta hyötyä, koska useimmat nominaalirakenteet voidaan substituoida sivulauseella. Siirryttäessä suomalaisugrilaisiin näkymiin asia saattaa muuttua toiseksi. Mainittakoon tässä vain, että esim. tšeremississä on runsaasti verbaalinominiin perustuvia enimmäkseen temporaalisia rakenteita, joille ei ole olemassa minkäänlaista sivulausevastinetta (ks. KangasmaA-MINN The Syntactical Distribution of the Cheremis Genitive s. 169--).

Verbin nominaalirakenteen muodostamasta lauseenvastikkeesta on olemassa myös avarampi selitys. O. IkoLan mukaan esim. lausetyyppiin Annan ammeeseen valua vettä sisältyy lauseenvastike ammeeseen valua vettä sen vuoksi, että siinä $\mathrm{n}$ o m in a a l i m u ot o o n li ittyy subjekti (ks. Vir. 1954 s. 217). Tällä tavalla käsitetyn lauseenvastikkeen ei siis tarvitse olla sijaistettavissa sivulauseella, koska huomiota kiinnitetään vain siihen, onko ilmauksessa lauseenjäseniä, ennen muuta tietysti pääjäseniä, vastaavat jäsenet. Tämän käsitystavan mukaan nekin nominaalirakenteet, joita edellä ei ole luettu lauseenvastikkeihin, kuuluvat niihin.

Lauseenvastike-käsitettä on mielenkiintoista tarkastella vielä yhdestä näkökulmasta. Modaalisen lausetyypin ${ }^{11}$ Sinähän aiot jättää

11 "Modaalinen on sellainen lause, jossa objektina olevan infinitiivin subjektipersoona on sama kuin peruslauseen subjekti" (SIRo SKL s. 89). 
yliopiston SIRo selittää siten, että siinä on peruslause Sinähän aiot O:n (tai $0: t a)$ (O tarkoittaa peruslauseen objektia) ja piilevänä toinen lause Sinähän jätät yliopiston (SKL s. 89-91). Myös esim. lausetyyppi Hän kumartui ottamaan oksaa maasta voidaan hänen mukaansa analysoida kahdeksi päälauseeksi, joista jälkimmäisen predikaattia edustaa infinitiivi (mts. 107). Näissä lausetyypeissä on siis toisin sanoen kysymys eräänlaisista päälauseen vastikkeista. Samaan tulokseen tullaan hiukan toisenlaistakin selitystä käyttämällä: koska puheena olevissa lauseissa infinitiiveillä (jättä̈ä, ottamaan) on muuhun lauseenjäseneen kätkeytynyt subjekti (sinähän, hän) (ks. s. 86), niiden voidaan tekijöineen katsoa omalla tavallaan edustavan täydellistä lausetta. Toteamus on laajennettava koskemaan muitakin nominaalirakenteeseen kuulumattomia infinitiivejä ja lisäksi partisiippeja, jotka eivät muodosta nominaalirakennetta eivätkä kuulu liittotempukseen, koska näillä kaikilla on joko muuhun lauseenjäseneen kätkeytynyt tai ajatussubjekti. Edellä olevat tulkinnat korostavat nominaalimuotojen verbinluonteisuutta uudesta näkökulmasta; vanhastaan on jo todettu nominaalimuotojen muistuttavan finiittimuotoja siinä, että ne saavat verbin määritteitä (SETÄL̈̈ SKL s. 106). Nominaalimuodoilla on kyllä lauseen kokonaisstruktuurin niiltä vaatimia kiistämättömiä nominin ominaisuuksia, kuten suhteellisen runsas sijataivutus ja esiintyminen nominien kanssa samoina lauseenjäseninä. Näihin tarvitsee kuitenkin kiinnittää huomiota vain silloin, kun puhutaan nominaalimuodoista alisteisina, sillä alistavina ne ovat tärkeimmiltä ominaisuuksiltaan verbin finiittimuotoihin verrattavia.

Sen, että lauseenvastike-termillä on tarkoitettu ilmauksia, erityisesti verbien nominaalirakenteita, jotka ovat korvattavissa sivulauseella (esim. Pentrilä), toisaalta myös muita nominaalimuotojen esiintymiä, joilla on oma subjekti (O. IKoLA), ja että sillä voidaan tarkoittaa vielä muutakin, ei tarvitse olla pelkästään puute, sillä niin kuin PaAvo Ravila on huomauttanut, useimmat kielitieteelliset peruskäsitteemme ovat vailla määritelmää, joka olisi joka suhteessa moitteeton eikä antaisi aihetta ristiriitaisuuksiin (Vir. 1962 s. 208). Kun nyt käsite, niin kuin lauseenvastike, on monimielinen, sen tarkoituksen on ilmettävä käyttöyhteydessä. Todellisesta puutteestahan on kysymys vasta silloin, kun jotakin käsitettä käytetään tietämättä, mitä sillä tarkoitetaan. 
Tämän kirjoituksen oltua jo suurin piirtein valmis saapui Virittäjän viime vuoden toinen vihko, jossa PAULI SAUkkonen on esittänyt mielenkiintoisia ajatuksia rakenteista, joihin kuuluu 1. infinitiivin lyhyempi muoto (1. infinitiivin lauseopillinen jäsentyminen, Vir. 1966 s. 153-). Saanen vielä lyhyesti puuttua hänen artikkeliinsa.

SAUKKONEN osoittaa, että ns. modaaliseen verbiin, esim. aion, ehdin, voin ${ }^{12}$, liittyvän 1 . infinitiivin lyhyemmän muodon perinnäistä jäsentämistä objektiksi voidaan monestakin syystä kritisoida (Vir. 1966 s. 158-). Konneksioissa aion, ehdin, voin jne. tehdä, joissa 1. infinitiivin latiivi liittyy kiinteästi vaillinaiseen verbiin, on hänen mukaansa parempi puhua infiniittisen pääverbin ja finiittisen apuverbin muodostamasta li ittop redika tista (s. 159). Myös tyyppejä nauraa hohotti ja oli pudota voi hänen mielestään hyvin pitää liittopredikaatteina (s. 161).

Radikaalisinta poikkeusta perinnäisistä jäsennyskaavoista merkitsee kuitenkin se, että SAUKKONEN ehdottaa varovasti kirjoituksensa

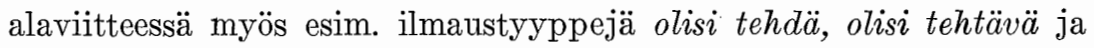

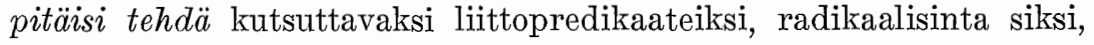
että tekijän ollessa genetiivissä, esim. is änn $\ddot{a} n$ pitää olla talossa, jouduttaisiin subjektin sijaksi kelpuuttamaan myös g e n e ti i vi (ks. Vir. 1966, alaviite s. 161-). Kielioppimme määrittelevät subjektin kahdella tavalla: 1. subjekti on predikaatin tekijä (loog. tai sis. määritelmä), 2. subjektin sijat ovat nominatiivi ja partitiivi (muod. määritelmä) (ks. esim. SEтÄLӓ SKL, s. 9, 10). Määritelmät joutuvat ristiriitaan silloin, kun verbin finiittimuodon tekijä ei ole nominatiivissa eikä partitiivissa, vaan esim. genetiivissä, kuten edellä. Genetiivisubjektin mukaanotto olisi askel kohti yhtenäisyyttä, kallistumista loogiseen määritelmään, mutta on huomattava, että sekään ei ratkaisisi koko subjektikysymystä. Lisäksi tulisi vielä kaksi muuta sijaa, sillä predikaatin tekijä voi exäissä tapauksissa olla myös adessiivissa tai elatiivissa: Minulla on sinut | Pojasta tuli mies. Subjekti-käsite yksinkertaistuisi tällä tavalla, mutta miten kävisi predikaatin?

On tietysti niin kuin SAuKKoNEN kirjoittaa, että genetiivi-

12 Näitä verbejä SIRo kutsuu modaalisiksi sen vuoksi, että eräissä tapauksissa verbin ja infinitiivin muodostama sanaliitto vastaa potentiaalia (SKL s. 91; ks. myös SAUKKONEN Vir. 1962 s. 160). 
subjekti yksinkertaistaisi kielioppia (Vir. 1966, alaviite s. 162), mutta näin tapahtuisi hänen jäsennystapaansa noudattamalla vain verbien nominaalirakenteiden osalta, ja vastapainoksi sitten predikaattikäsite samalla laajenisi miltei muodottomaksi. Ei nimittäin

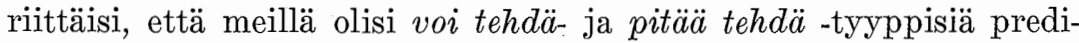
kaatteja monine erilaisine tempus- ja modusmahdollisuuksineen (edellisessä tapauksessa sitä paitsi jo apuverbien lukumäärä on huomattavan suuri), sillä myös kerrostuneemmat tyypit voi saada tehdä

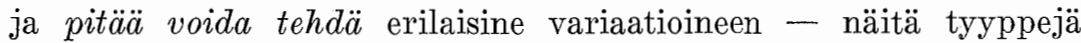
SAUKKoNEN ei lainkaan mainitse — ovat olemassa (vai millä tavalla ne olisi jäsennettävä?).

Subjektin määritelmän yhtenäistäminen tuntuisi ensi näkemältä hyvin tervetulleelta uudistukselta, mutta jollei sitä voida saada aikaan muuten kuin laajentamalla predikaatti-käsitettä SAUKKOSEN ehdottamalla tavalla, on kysymys siksi perinpohjaisesta lauseopillisten peruskäsitteidemme mullistamisesta, että sen toteuttamiseen tarvitaan erityisen vahvat perustelut. Koska SAUkkosen ehdotuksista (liittopredikaatti, genetiivisubjekti) ei ole vielä tarpeeksi monipuolista näkemystä, olisi toivottavaa, että syntyisi keskustelu, jossa niiden hyvät samoin kuin huonotkin puolet tulisivat perusteellisesti pohdituiksi.

Pienen ylimääräisen poikkeamisen aiheuttanut SAUkKosEN artikkeli viittaa siihen, että verbien nominaalimuotoihin liittyvät käsityksemme kaipaavat jatkuvaa tarkistamista. Erityisen mielenkiintoista tehtävää syntaktisella tutkimuksella on vielä kosolti kielemme synteettistä erikoislaatua korostavan runsaan verbien nominaalirakenteiston selvittelyssä.

\section{Pentri Vartiainen: Über die Nominalkonstruktionen der finnischen Verben}

Der Verfasser betrachtet in seinem Aufsatz folgende syntaktische Konstruktionen: Partizipial-, Temporal- und Finalkonstruktionen, Quasi-, Modal- und Quantumkonstruktionen, Fatum-, Agens- und Intensitätskonstruktionen, Infinitiv- 
konstruktionen, Attributkonstruktionen sowie eine Anzahl Konstruktionen, denen bisher eine Benennung abgeht.

Die syntetische Eigenart der finnischen Sprache wird u.a. gerade durch die Vielfalt an Nominalkonstruktionen der Verben akzentuiert. Die oben angeführten Konstruktionen, deren jede in der Satzanalyse als ein zusammenhängendes Ganzes betrachtet wird, übersetzt man in eine idg. Sprache am zweckmässigsten mit einem Nebensatz oder einem sonstigen analytischen Gefüge.

In Anlehnung an grammatische Schemata aus verschiedenen Fremdsprachen werden die Nominalformen der Verben in den finnischen Grammatiken schon seit langem auf analytischem Wege erklärt. Dass die Nominalkonstruktionen der Verben erst allmählich in der Sprache entdeckt und benannt wurden, ist als hauptsächliche Ursache für die Heterogenität und teilweise Verworrenheit der Nomenklatur zu betrachten. Verwirrung stiftet vor allem der Umstand, dass die Benennungsgrundlagen - die formale und die inhaltliche - in manchen Fällen übereinandergreifen. Alle Konstruktionen hätten in Verfolgung eines und desselben Prinzips benannt werden müssen, wobei formal begründete Benennungen die deutlichsten wären. Die heutigen Benennungen sind jedoch schon so fest eingebürgert, dass eine Veränderung wohl ausserhalb der Möglichkeiten fällt.

Einen Schritt weiter wäre man schon, wenn die durch ihre eigene Spezialbedeutung ein wenig irreführenden Bezeichnungen Infinitiv- und Partizipialkonstruktion auch ihrer natürlichen Bedeutung gemäss verwendet würden, d.h. sozusagen als Universalbenennungen, die für jede beliebige, auf einem Infinitiv oder Partizip basierende Konstruktion in Frage kämen.

Bei der Analyse der Nominalkonstruktionen der Vèrben gelten die herkömmlichen Benennungen Subjekt- und Prädikatteil. Man bezeichnet damit die dem Subjekt und dem Prädikat entsprechenden Satzteile desjenigen Nebensatzes, der gewöhnlich als Ersatz einer Konstrulktion oben angeführter Art möglich ist. Der Verf. schlägt vor, diese Benennungen durch die Termini Subjekt und Prädikat der Konstruktion zu ersetzen. Die Benennungen Subjekt- und Prädikatteil werden dann frei, um in einer Konstruktion das Subjekt oder das Prädikat zusammen mit ihren Bestimmungen zu bezeichnen.

Die Benennung Konstrüttion eignet sich von rein grammatischem Standpunkt aus nicht als Bezeichnung von Ausdrücken, die doch herkömmlicherweise als Konstruktionen gelten, z.B. haluttaessa (Temporalkonstruktion) oder maaten (Modalkonstruktion), weil diese syntaktisch nicht zerlegbar sind und demnach keine Konstruktionen im eigentlichen Sinn darstellen. Auf logischer Ebene verhält es sich jedoch anders, weil die erwähnten Ausdrücke ein gedachtes Subjekt voraussetzen und deshalb als Konstruktionen zu betrachten sind. Zur Hervorhebung der Eigenart soleher Konstruktionen wird im Aufsatz die Benennung verdeclete Konstruktion vorgeschlagen.

Für den Unterschied zwischen den einfachen Nominalformen des Verbs und denjenigen Nominalformen, die zur Bildung von Nominalkonstruktionen verwendet werden, gibt der Verf. folgende Definition: Die Nominalkonstruktion stellt lediglich einen Ausdruckstypus dar, bei dem die Nominalform - abgesehen 
von den Passivfällen - entweder ein faktisches oder gedachtes, in formaler Beziehung separates Subjekt besitzt. Als solches ist sogar ein Possessivsuffix möglich.

Das Verhältnis zwischen Prädikat und Subjekt der Nominalkonstruktion und das von diesen beiden Elementen gebildete Wortgefüge wird vom Verfasser in der Nachfolge Jespersens Nexus genannt. Eine Konstruktion ohne grammatisches Subjekt besitzt einen verdeckten Nexus.

Festgestellt wird weiterhin, dass der Terminus Satzentsprechung in Bezug auf die Nominalformen der Verben zwei Sachen bezeichnet: 1. eine Konstruktion, an deren Stelle ein Nebensatz möglich ist (z.B. Penttilä, Suomen kielioppi, § 453); 2. eine Konstruktion, deren Elemente zumindest den Hauptgliedern eines Satzes entsprechen (Osmo Ikola, Vir. 1954, S. 217). Die Benennung Satzentsprechung gilt ausserdem noch für eine ganze Reihe sonstiger Ausdrücke, weil sie einem Nebensatz entsprechen. Der Terminus ist also vieldeutig und sein jeweiliger Sinn muss infolgedessen aus der Art seiner Anwendung ersehen werden.

Nur einige von den vielfältigen Problemen, die im Zusammenhang mit den Nominalkonstruktionen der Verben stehen, konnten in vorliegendem Artikel erörtert werden. Eine fortlaufende Revision der auf diesem Gebiet herrschenden Auffassungen erscheint angezeigt. 